\title{
SYNTHESIS, CHARACTERISATION MOLECULAR DOCKING WITH DENGUE AND HUMAN DNA OF ANTIPYRINE BASED TRANSITION METAL COMPLEXES
}

\author{
K.N. Gita ${ }^{1, \bowtie}$, V. Chanrasekaran ${ }^{2}$ and P. Akilan ${ }^{2}$ \\ ${ }^{1}$ Department of Chemistry, Government Arts College for Women, Salem-636008, India \\ ${ }^{2}$ Department of Chemistry, Government Arts College (Autonomous), Salem-636007, India \\ ${ }^{\circledR}$ Corresponding Author: gitakn27@gmail.com
}

\begin{abstract}
The $\mathrm{Cu}(\mathrm{II}), \mathrm{Ni}(\mathrm{II}), \mathrm{Zn}(\mathrm{II})$ and V(IV) (1-4) metal complexes were synthesized using 4-aminoantipyrine based ligand by refluxing with corresponding metal salts. A Schiff base ligand (L) was synthesized by condensing 3,5dichlorosalicylaldehyde and antipyrine. The binding energy values of complexes 1-4 with human DNA (PDB I.D: 1BNA) and dengue protein virus (PDB ID: 2VBC) were calculated by using vina software. The calculated energy values of metal complexes 1-4 were respectively -7.4, -7.3, -3.6 and $-3.7 \mathrm{kcal} \mathrm{mol}^{-1}$ for $2 \mathrm{VBC}$, while the binding energy values of 1-4 metal complexes were found to be $-9.0,-8.8,-8.6$ and $-8.9 \mathrm{kcal} \mathrm{mol}^{-1}$ which towards $1 \mathrm{BNA}$.
\end{abstract}

Keywords: 3,5-dichlorosalicylaldehyde, 4-Aminoantipyrine, Schiff Base Ligand, Docking Studies.

RASĀYAN J. Chem., Vol. 14, No.2, 2021

\section{INTRODUCTION}

Dengue is a typical human arbovirus disease comprehensively. ${ }^{1,2}$ The World Health Organization (WHO) assesses a yearly rate of roughly 100 million contaminations, with around 500,000 individuals with dengue haemorrhagic fever (DHF) requiring hospitalization, and a huge extent of them being kids. ${ }^{3}$ As the occurrence of dengue and DHF is expanding, uncommon appearances are on the ascent, even though they are being under revealed because of the absence of mindfulness. ${ }^{4}$ Neurological signs so far revealed incorporate wretchedness, seizures, encephalopathy, encephalitis, aseptic meningitis, intracranial discharge, intracranial apoplexy, myelitis, mononeuropathies, polyneuropathies, hemifacial fit, fringe facial loss of motion and Guillain-Barre disorder (GBS) ${ }^{5-7}$ GBS or intense fiery demyelinating polyradiculopathy (AIDP) is a post irresistible rising, normally demyelinating, polyradiculoneuropathy joined by areflexia, engine loss of motion, and raised cerebro spinal liquid (CSF) complete protein without pleocytosis. ${ }^{8}$ Settled relationship with GBS is late contaminations with Campylobacter jejuni, Cytomegalo infection, Epstein-Barr infection, Mycoplasma pneumonia, HIV. Yet, dengue fever (DF) as forerunner contamination in GBS is phenomenal. ${ }^{9} \mathrm{~A}$ few past reports have depicted GBS in patients with dengue. ${ }^{10-12}$ The vast majority of these cases were kids and a couple of instances of post-dengue GBS in grown-ups. ${ }^{13}$ Herewith we present a grown-up instance of conceivable post-dengue GBS in Sri Lanka and this case calls for uncommon consideration because the dengue contamination stays a genuine general medical issue in numerous nations and the real rate of neurological complexities isn't very much revealed. The malady produces clinical infirmity running from harmless regular fever to a savage hemorrhagic fever (DHF) depicted by thin spillage and thrombocytopenia. Furthermore, it may show into the mistake of the stream system and daze, named as dengue paralyze scatter (DSS) that may prompt passing. ${ }^{14-17}$ The WHO reports says there were around 6,00,000 peoples were affected by the dengue virus all around the world. ${ }^{18-20}$ The virus has four stages. ${ }^{21}$ So it is necessary to discover a drug for the virus.

\section{EXPERIMENTAL}

The chemicals were purchased in AR grade and used as purchased. The solvents were purchased and used as the original quality. 
RASĀYAN J. Chem.

Vol. 14 | No. 2 |1230-1239| April - June | 2021

\section{Synthesis of Ligand (L)}

Using ethanol $(5 \mathrm{~mL})$ the 4-aminoantipyridine was dissolved and then add methonolic solution of 3,5dichlorosalicylaldehye. After $18 \mathrm{hr}$, there is a yellow solid appears from the reaction. The yellow solid was filtered and washed with ether (Scheme-1).

Chemical Formula: $\mathrm{C}_{18} \mathrm{H}_{15} \mathrm{Cl}_{2} \mathrm{~N}_{3} \mathrm{O}_{2}$. Elemental Analysis: C, 57.46; H, 4.02; N, 11.17; O, 8.50 \%. IR ( $\mathrm{KBr}$ pellets) $v$ cm-1:3415 (v $\mathrm{O}-\mathrm{H}), 1648(v \mathrm{C}=\mathrm{N}), 1695(v \mathrm{C}=\mathrm{O})$; UV-Vis $(\lambda \max , \mathrm{nm}) \mathrm{ACN}$ : Chloroform(1:1): 359, 279, 245 and 224.

\section{Synthesis of Metal Complexes}

Using the reflux method, the complexes 1-4 were synthesized. The L (1eq.) and the metal salt in $\mathrm{MeOH}$ were added slowly to the walls of the RB flask and then refluxed. The insoluble solid mass was appearing within one hour then cooled and filtered. The metal complexes were washed with a methanol/water $(1: 1)$ mixture.

\section{Synthesis Copper (II) L Metal Complexes}

Copper chloride (1mmol) and L (1mmol), Refluxing time $1 \mathrm{~h}$, Color of the complex -brown, Yield (86\%). Chemical Formula: $\mathrm{C}_{18} \mathrm{H}_{14} \mathrm{Cl}_{3} \mathrm{CuN}_{3} \mathrm{O}_{2}$. Elemental Analysis: C, 45.59; H, 2.98; Cl, 22.43; $\mathrm{Cu}$, 13.40; N, 8.86; O, 6.75\%. IR (KBr pellets) v cm-1:3298 (v O-H), $1642(v \mathrm{C}=\mathrm{N}), 1713(v \mathrm{C}=\mathrm{O})$; Mass spectra: $475.51 \mathrm{~m} / \mathrm{z}$ base peak $(\mathrm{M}+1)$.

\section{Synthesis of Nickel (II) L Metal Complexes}

Nickel chloride (1mmol) and L (1mmol), Refluxing time $1 \mathrm{~h}$, Color of the complex -red, Yield (73\%).

Chemical Formula: $\mathrm{C}_{18} \mathrm{H}_{14} \mathrm{C}_{13} \mathrm{~N}_{3} \mathrm{NiO}_{2}$. Elemental Analysis: $\mathrm{C}, 46.06 ; \mathrm{H}, 3.01 ; \mathrm{Cl}, 22.66 ; \mathrm{N}, 8.95 ; \mathrm{Ni}$, 12.50; O, 6.82\%. IR ( $\mathrm{KBr}$ pellets) $v \mathrm{~cm}^{-1}: 3265(\mathrm{v} \mathrm{O}-\mathrm{H}), 1647(\mathrm{v} \mathrm{C}=\mathrm{N}), 1690(\mathrm{v} \mathrm{C}=\mathrm{O})$; Mass spectra: $470.05 \mathrm{~m} / \mathrm{z}$ base peak $(\mathrm{M}+1)$.

\section{Synthesis of Zine (II) L Metal Complexes}

Zinc chloride (1mmol) and $\mathrm{L}(1 \mathrm{mmol})$, Refluxing time $1 \mathrm{~h}$, Color of the complex -pale yellow, Yield (85\%). Chemical Formula: $\mathrm{C}_{18} \mathrm{H}_{14} \mathrm{C}_{13} \mathrm{~N}_{3} \mathrm{O}_{2} \mathrm{Zn}$. Elemental Analysis: C, 45.41; H, 2.96; Cl, 22.34; N, 8.83; $\mathrm{O}, 6.72 ; \mathrm{Zn}, 13.74 \%$. IR (KBr pellets) $v \mathrm{~cm}^{-1}: 3320(v \mathrm{O}-\mathrm{H}), 1635(v \mathrm{C}=\mathrm{N}), 1698(v \mathrm{C}=\mathrm{O})$; Mass spectra: $477.73 \mathrm{~m} / \mathrm{z}$ base peak $(\mathrm{M}+1)$.

\section{Synthesis of Vanadium (IV) L Metal Complexes}

Vanadyl sulphate (1mmol) and L (1mmol), Refluxing time $1 \mathrm{~h}$, Color of the complex -green, Yield (81\%). Chemical Formula: $\mathrm{C}_{19} \mathrm{H}_{18} \mathrm{C}_{12} \mathrm{~N}_{3} \mathrm{O}_{4} \mathrm{~V}$ Elemental Analysis: C, 48.12; H, 3.83; Cl, 14.95; N, 8.86; O, 13.50; V, 10.74\%. IR (KBr pellets) $v \mathrm{~cm}^{-1}: 3350(v \mathrm{O}-\mathrm{H}), 1640(\mathrm{v} \mathrm{C}=\mathrm{N}), 1672(\mathrm{v} \mathrm{C}=\mathrm{O})$; Mass spectra: $475.43 \mathrm{~m} / \mathrm{z}$ base peak $(\mathrm{M}+1)$.

\section{IR Spectrum of Ligand $L$ and Complexes $9-12$}

\section{RESULTS AND DISCUSSION}

The FT-IR spectrum confirms the functionality present in the ligand and the metal complexes. In the IR spectrum, the $\mathrm{O}-\mathrm{H}$ group present in the phenyl ring represents $3415 \mathrm{~cm}^{-1}$ for ligand. When the complex takes place the values of the O-H shift towards $3298,3265,3320$ and $3350 \mathrm{~cm}^{-1}$ which denotes the complex formation. In here the ketone group present in the ring for $1701 \mathrm{~cm}^{-1}$ which shifted to 1713 , 1690,1698 and $1672 \mathrm{~cm}^{-1}$ denotes the moiety involves in the complexation.

The IR peaks $519,530,545$ and $561 \mathrm{~cm}^{-1}$ for complexes 1-4 represent the metal-ligand bond formations. The FT-IR images were shown in Fig.-1.

\section{Electronic Spectra}

The electronic spectra explain the electronic transition between ground and excited state electronic transitions. The ligand having the electronic transition of 223, 271 and $332 \mathrm{~nm}$ targets the $\pi-\pi^{*}$ and $\mathrm{n}-\pi^{*}$ electronic transition. The $\mathrm{n}-\pi^{*}$ transition confirms the Schiff base formation. The copper complex having an absorption band at 227, 269, 363 and $595 \mathrm{~nm}$. Especially $595 \mathrm{~nm}$ peak denotes the ${ }^{1} \mathrm{~A}_{1 \mathrm{~g}} \rightarrow{ }^{1} \mathrm{~B}_{1 \mathrm{~g}}$ electronic transition. The copper complex having square planar geometry. 
RASĀYAN J. Chem.

Vol. 14 | No. 2 |1230-1239| April - June | 2021

The nickel complex having the electronic transition of $\pi-\pi^{*}, \mathrm{n}-\pi^{*},{ }^{1} \mathrm{~A}_{1 \mathrm{~g}} \rightarrow{ }^{1} \mathrm{~B}_{2 \mathrm{~g}}$ and ${ }^{1} \mathrm{~A}_{1 \mathrm{~g}} \rightarrow{ }^{1} \mathrm{~B}_{1 \mathrm{~g}}$ for the peaks at 224, 359, 420 and $540 \mathrm{~nm}$. The ${ }^{1} \mathrm{~A}_{1 \mathrm{~g}} \rightarrow{ }^{1} \mathrm{~B}_{2 \mathrm{~g}}$ electronic transition explains the distorted octahedral form and having a square planar configuration. The zinc complex does not have the d-d electronic transition and it has the peak shift at $\mathrm{n}-\pi^{*}$ excitation and has tetrahedral geometry. The vanadium complex has square pyramidal geometry which has the electronic excitation transition of ${ }^{2} \mathrm{~B}_{2} \rightarrow{ }^{2} \mathrm{~B}_{1}$ and ${ }^{2} \mathrm{~B}_{2} \rightarrow{ }^{2} \mathrm{E}$. The UV-Vis data were shown in Table-2 and the images were shown in Fig.-2.

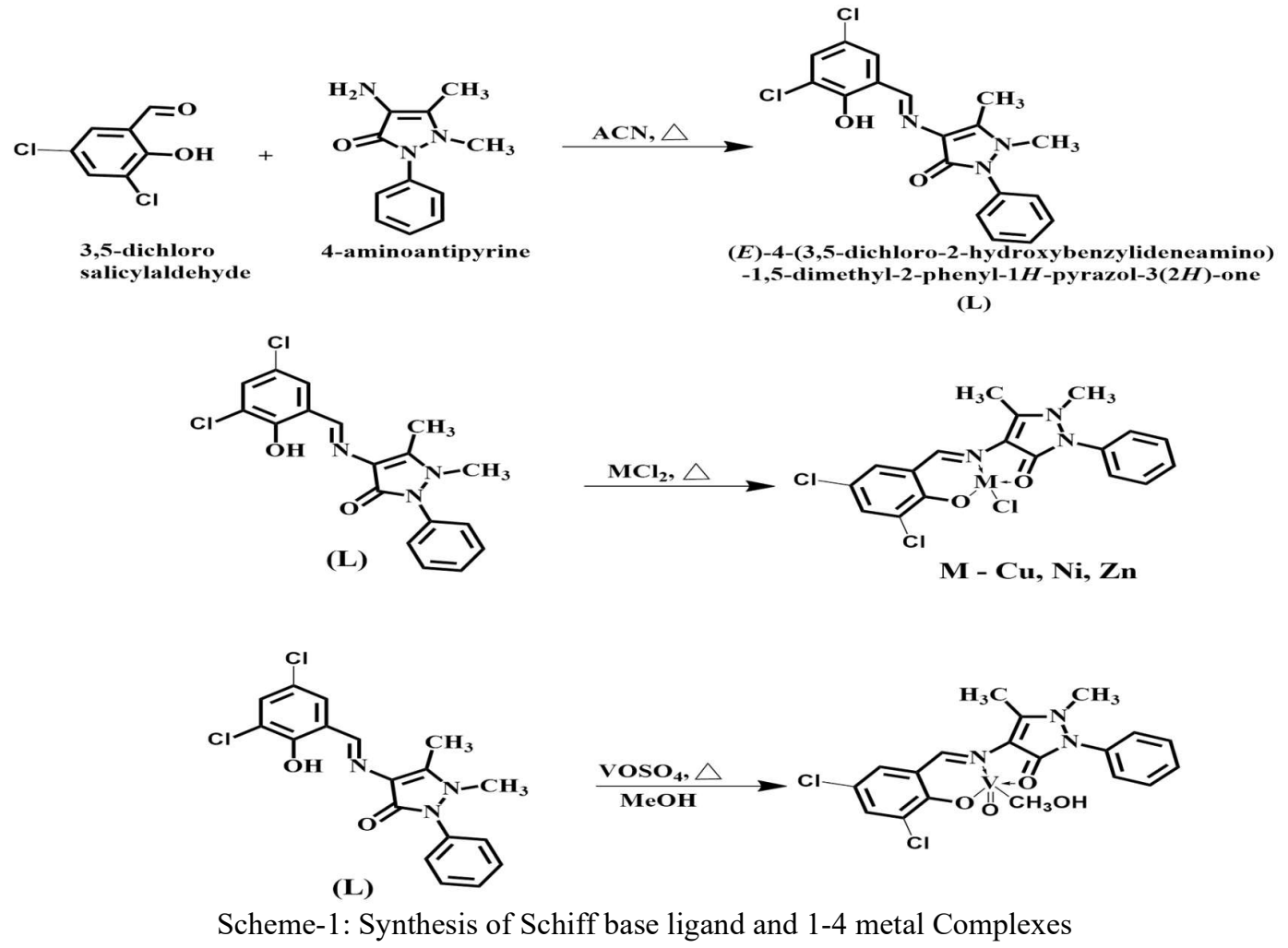

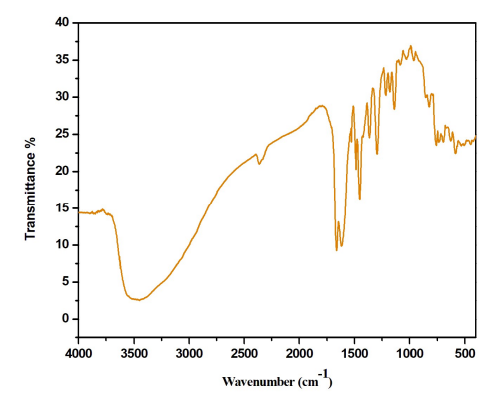

(a)

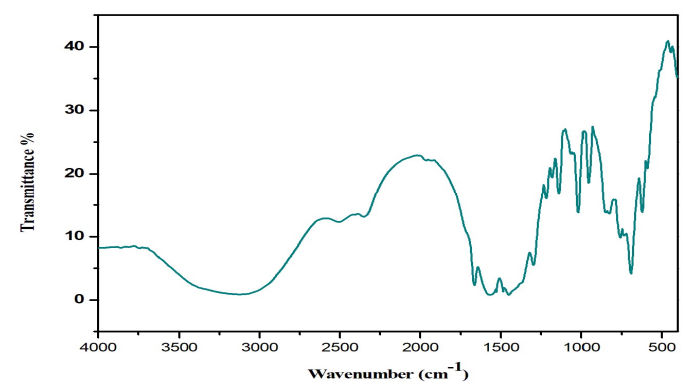

(d)

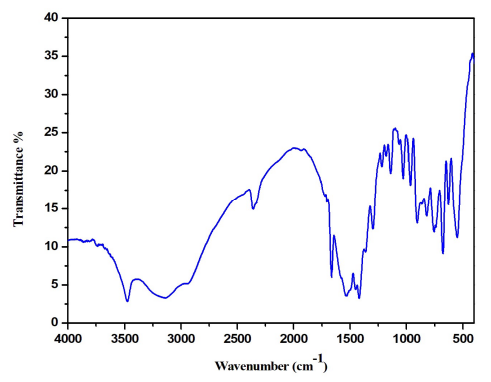

(b)

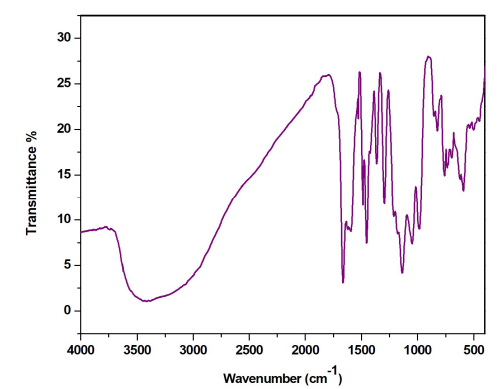

(c)

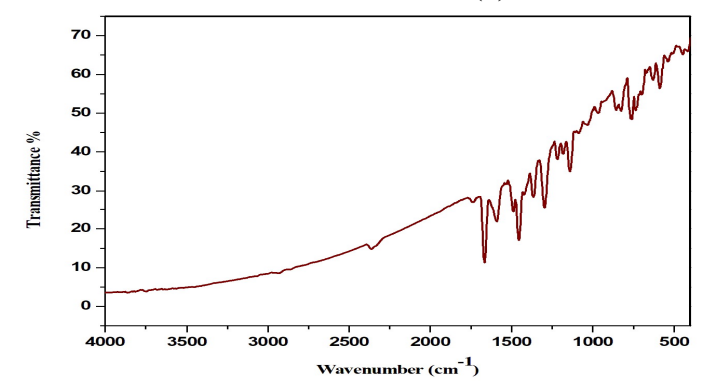

(e)

Fig.-1: FT-IR Spectra of L and Complexes 1-4 
RASĀYAN J. Chem.

Vol. 14 | No. 2 |1230-1239| April - June | 2021

Table-1: UV Data of Ligand L and Metal Complexes 1-4

\begin{tabular}{c|c|c}
\hline Compound & $\lambda_{\max }(\mathrm{nm})$ & Assignment \\
\hline $\mathrm{C}_{18} \mathrm{H}_{15} \mathrm{C}_{12} \mathrm{~N}_{3} \mathrm{O}_{2}[\mathrm{~L}]$ & 223 & $\pi-\pi^{*}$ \\
& 271 & $\mathrm{n}-\pi^{*}$ \\
& 332 & $\mathrm{n}-\pi^{*}$ \\
\hline $\mathrm{C}_{18} \mathrm{H}_{14} \mathrm{~N}_{3} \mathrm{O}_{2} \mathrm{Cl}_{3} \mathrm{Cu}[1]$ & 227 & $\pi-\pi^{*}$ \\
& 269 & $\mathrm{n}-\pi^{*}$ \\
& 363 & $\mathrm{LMCT}$ \\
& 595 & ${ }^{1} \mathrm{~A}_{1 \mathrm{~g}} \rightarrow{ }^{1} \mathrm{~B}_{1 \mathrm{~g}}$ \\
\hline $\mathrm{C}_{18} \mathrm{H}_{14} \mathrm{~N}_{3} \mathrm{O}_{2} \mathrm{Cl}_{3} \mathrm{Ni}[2]$ & 224 & $\pi-\pi^{*}$ \\
& 359 & $\mathrm{n}-\pi^{*}$ \\
& 420 & ${ }^{1} \mathrm{~A}_{1 \mathrm{~g}} \rightarrow{ }^{1} \mathrm{~B}_{2 \mathrm{~g}}$ \\
& 540 & ${ }^{1} \mathrm{~A}_{1 \mathrm{~g}} \rightarrow{ }^{1} \mathrm{~B}_{1 \mathrm{~g}}$ \\
\hline $\mathrm{C}_{18} \mathrm{H}_{14} \mathrm{~N}_{3} \mathrm{O}_{2} \mathrm{Cl}_{3} \mathrm{Zn} \mathrm{[3]}$ & 221 & $\pi-\pi^{*}$ \\
& 328 & $\mathrm{n}-\pi^{*}$ \\
\hline $\mathrm{C}_{19} \mathrm{H}_{18} \mathrm{~N}_{3} \mathrm{O}_{4} \mathrm{Cl}_{2} \mathrm{~V}[4]$ & 218 & $\pi-\pi^{*}$ \\
& 335 & $\mathrm{n}-\pi^{*}$ \\
& 457 & ${ }^{2} \mathrm{~B}_{2} \rightarrow{ }^{2} \mathrm{~B}_{1}$ \\
& 560 & ${ }^{2} \mathrm{~B}_{2} \rightarrow{ }^{2} \mathrm{E}$ \\
\hline
\end{tabular}

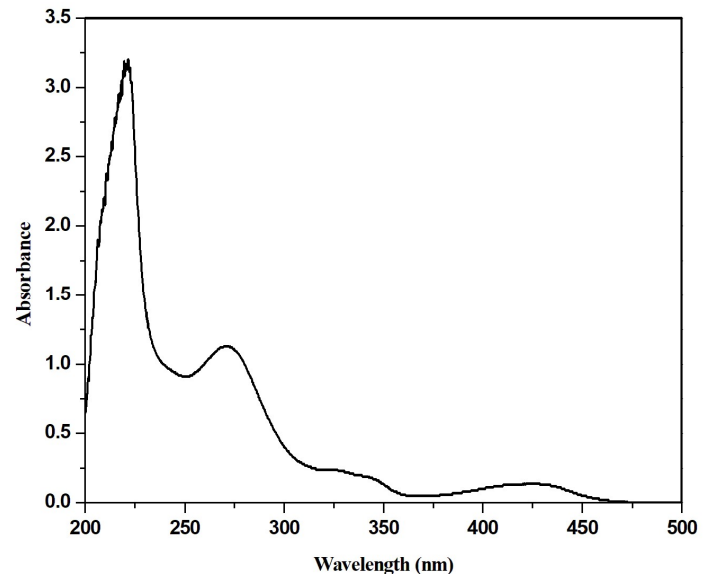

(a)

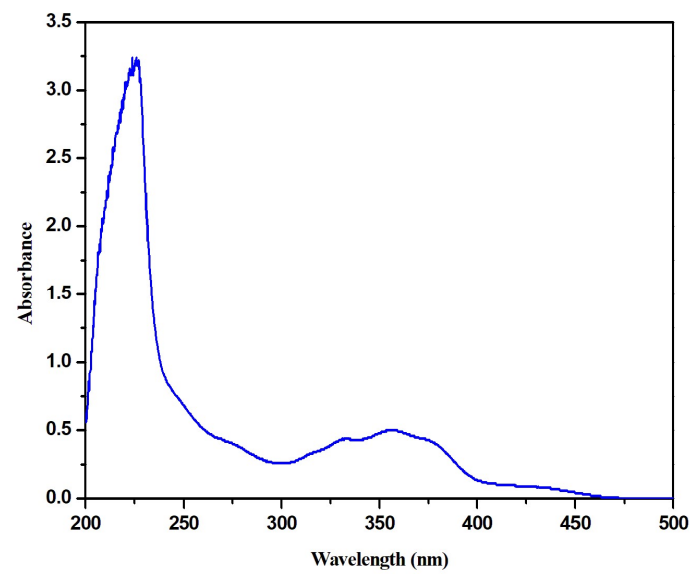

(c)

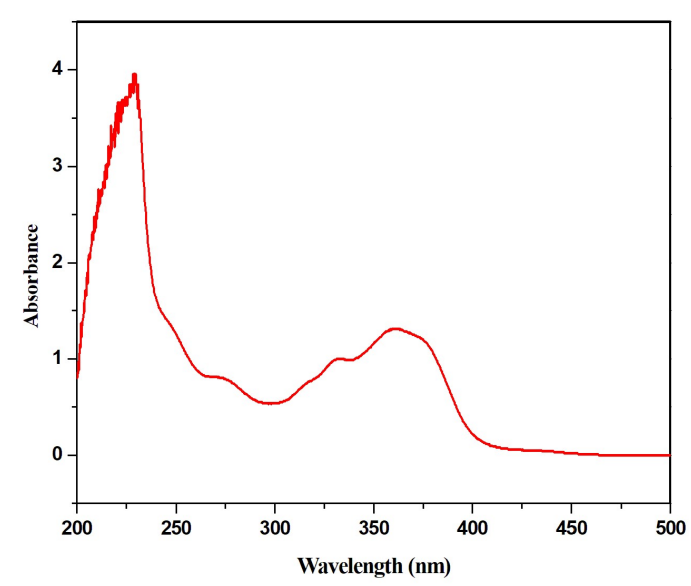

(b)

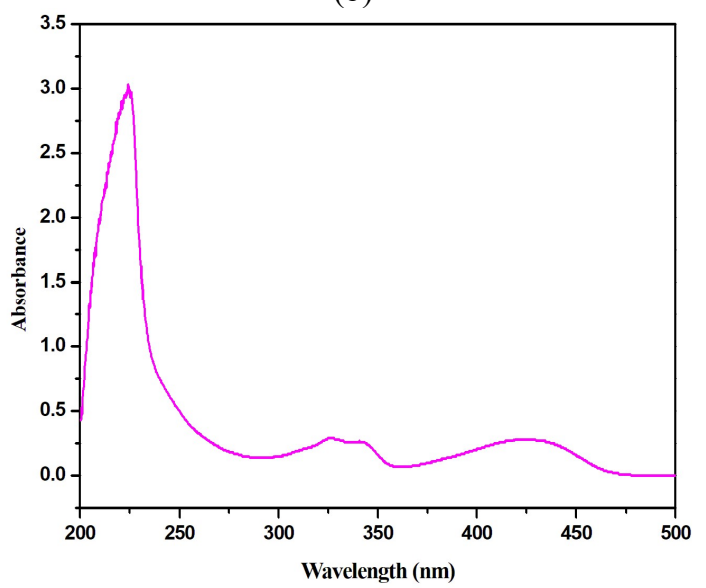

(d) 
RASĀYAN J. Chem.

Vol. 14 | No. 2 |1230-1239| April - June | 2021

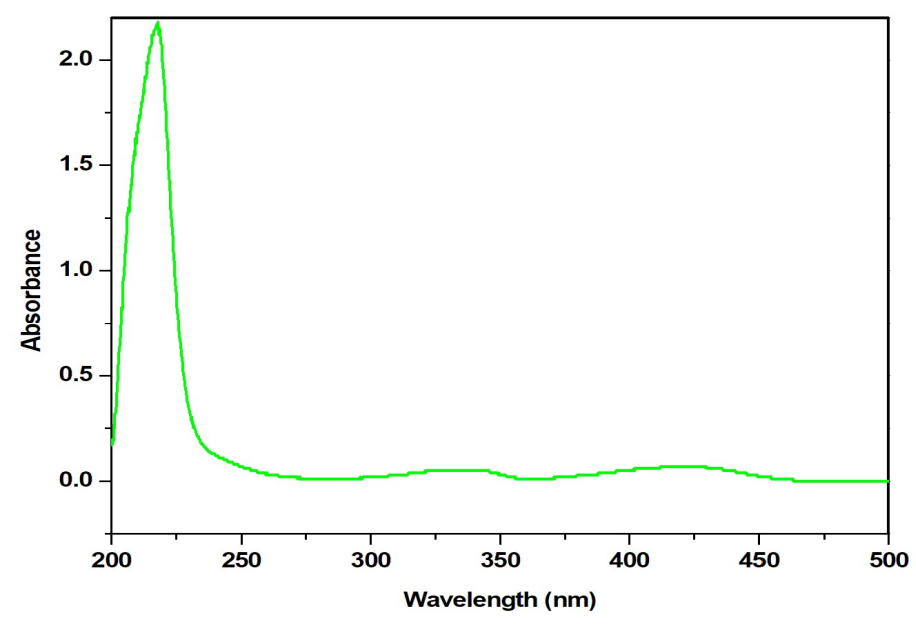

(e)

\section{Mass Spectrum}

Fig.-2: Absorption Spectrum of L and Complexes 1-4

A mass spectrum is one of the best methods to identify the total mass of the compound. For the ligand $\mathrm{L}$ and metal complexes, 1-4 having $\mathrm{M}+1$ ion as a base peak fragmentation which confirms the complex formation and the mass spectrum data were shown in the Table-2. The mass spectrums were displayed in Fig.-3.

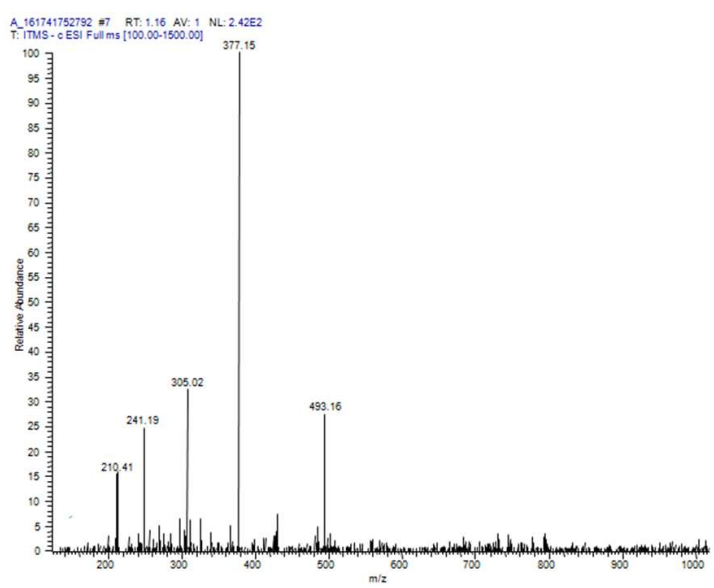

(a)

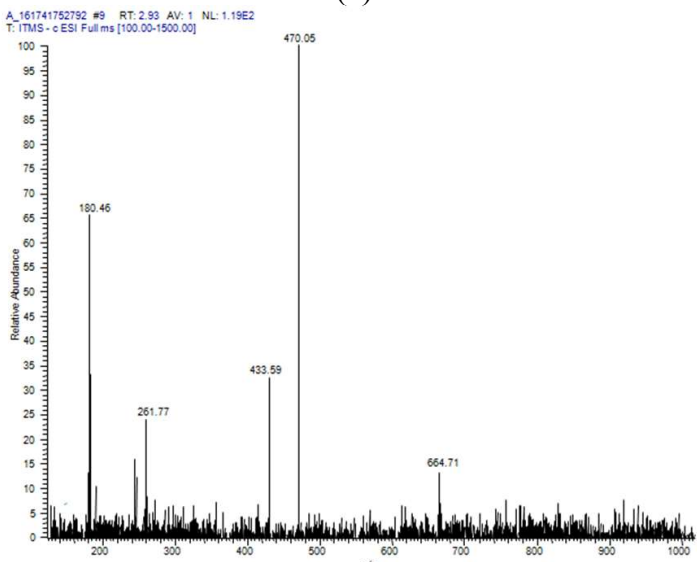

(c)

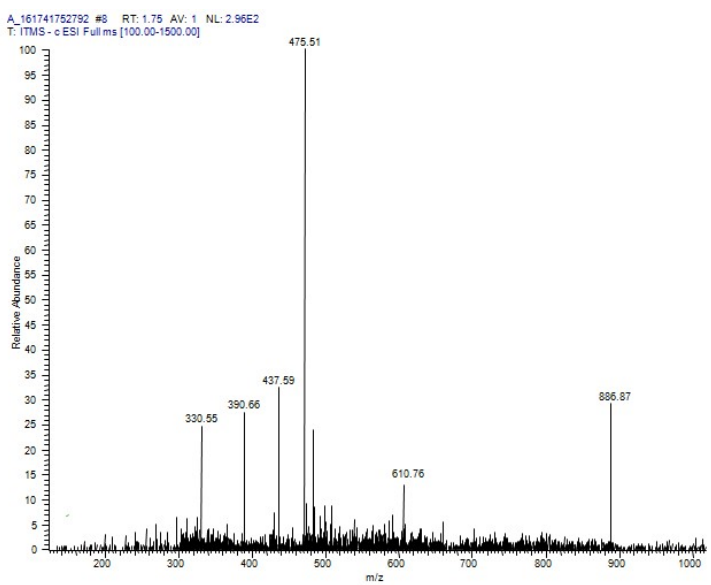

(b)

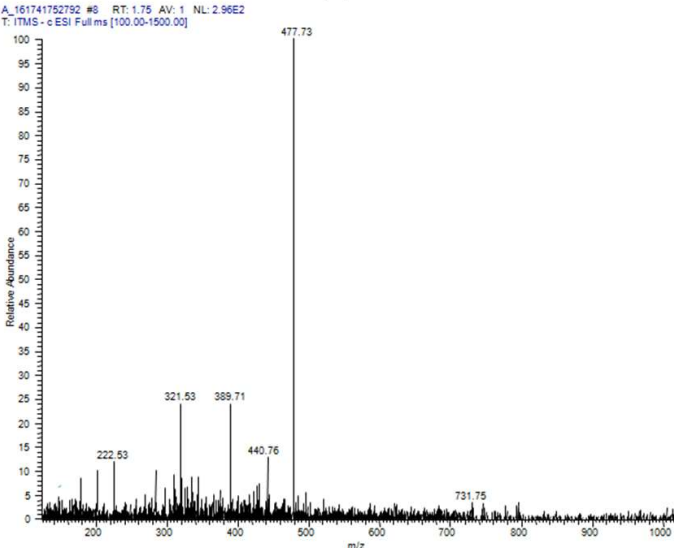

(d) 
RASĀYAN J. Chem.

Vol. 14 | No. 2 |1230-1239| April - June | 2021

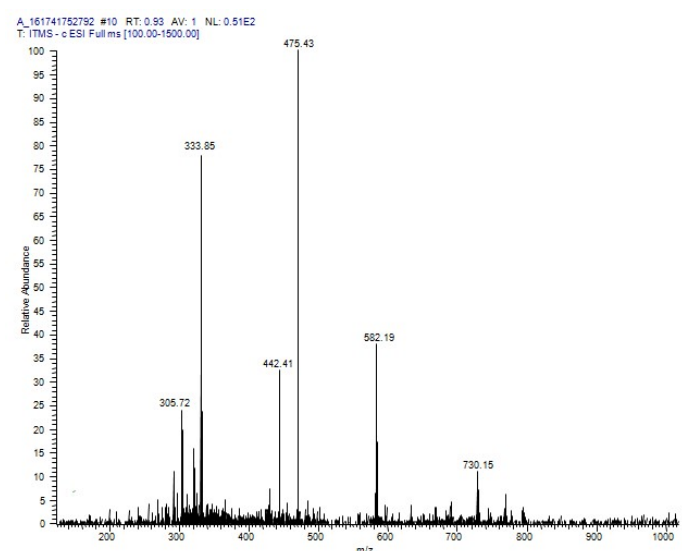

(e)

Fig.-3: ESI-MS Spectra of L and Complexes 1-4

Table-2: Mass Data for Ligand L and Metal Complexes 1-4

\begin{tabular}{c|c|c|c}
\hline Sample & Chemical Formula & Molecular Weight & Mass from Spectra \\
\hline L & $\mathrm{C}_{18} \mathrm{H}_{15} \mathrm{Cl}_{2} \mathrm{~N}_{3} \mathrm{O}_{2}$ & 376.24 & 377.15 \\
\hline Complex 1 & $\mathrm{C}_{18} \mathrm{H}_{14} \mathrm{~N}_{3} \mathrm{O}_{2} \mathrm{Cl}_{3} \mathrm{Cu}$ & 474.23 & 475.51 \\
\hline Complex 2 & $\mathrm{C}_{18} \mathrm{H}_{14} \mathrm{~N}_{3} \mathrm{O}_{2} \mathrm{Cl}_{3} \mathrm{Ni}$ & 469.38 & 470.05 \\
\hline Complex 3 & $\mathrm{C}_{18} \mathrm{H}_{14} \mathrm{~N}_{3} \mathrm{O}_{2} \mathrm{Cl}_{3} \mathrm{Zn}$ & 476.09 & 477.73 \\
\hline Complex 4 & $\mathrm{C}_{19} \mathrm{H}_{18} \mathrm{~N}_{3} \mathrm{O}_{4} \mathrm{Cl}_{2} \mathrm{~V}$ & 474.21 & 475.43 \\
\hline
\end{tabular}

\section{Computational Studies}

\section{Docking Studies with BDNA}

A molecular docking study is one of the best tools to understand drug-biomolecular interaction. This study can help to improve the already available drug potential and also helps to synthesis novel drugs for the suitable biomolecular target area. The synthesized metal complexes were used to dock with the DNA hexamer unit d(CGATCG)2 bi-functional enzyme B-DNA (PDB ID: 1BNA). All the synthesized complexes exhibit an intercalation mode of binding towards the targeted DNA molecule by considering the binding mode and the binding affinity. There will be nine possible confirmers in which the molecule attack nine different positions towards the DNA. The complexes interact with DT20, DT7, DA5, DT20, DT7, DA6, DC24, DT8 nucleotide of the DNA molecule. From the docking results complex 1 having great interaction and having great binding energy value. Based on the binding energy value the order of the best three compounds towards DNA molecules are $1>2>3>4$. For complex 1, the compound majorly interacts with the DNA molecule by using oxygen atom through Pi-Pi stacked interactions with the base pair. The binding modes of the synthesized complexes with DNA were shown in Fig.-4. The binding interactions of drug-DNA were noted in Table-3.

Table-3: Docking Interactions of Complexes 1-4 with DNA

\begin{tabular}{c|c|c|c|c}
\hline 1 & N4 & DT20 & -7.4 & 4.92 \\
\hline & N4 & DT7 & & 3.84 \\
\hline & C127 & DA5 & & 4.86 \\
\hline & C24 & DT20 & & 4.21 \\
\hline 2 & N4 & DT20 & -7.3 & 4.10 \\
\hline & N4 & DT7 & & 3.15 \\
\hline & C15 & DT20 & & 4.90 \\
\hline & C15 & DA6 & & 3.79 \\
\hline & C127 & DA6 & & 3.14 \\
\hline 3 & C24 & DC24 & -3.6 & 3.74 \\
\hline & C6-11 & DT8 & & 2.79 \\
\hline & C12 & DT8 & & 3.54 \\
\hline 4 & C6-11 & DT8 & -3.7 & 3.66 \\
\hline & Zn25 & DT8 & & 2.87 \\
\hline
\end{tabular}


RASĀYAN J. Chem.

Vol. 14 | No. 2 |1230-1239| April - June | 2021
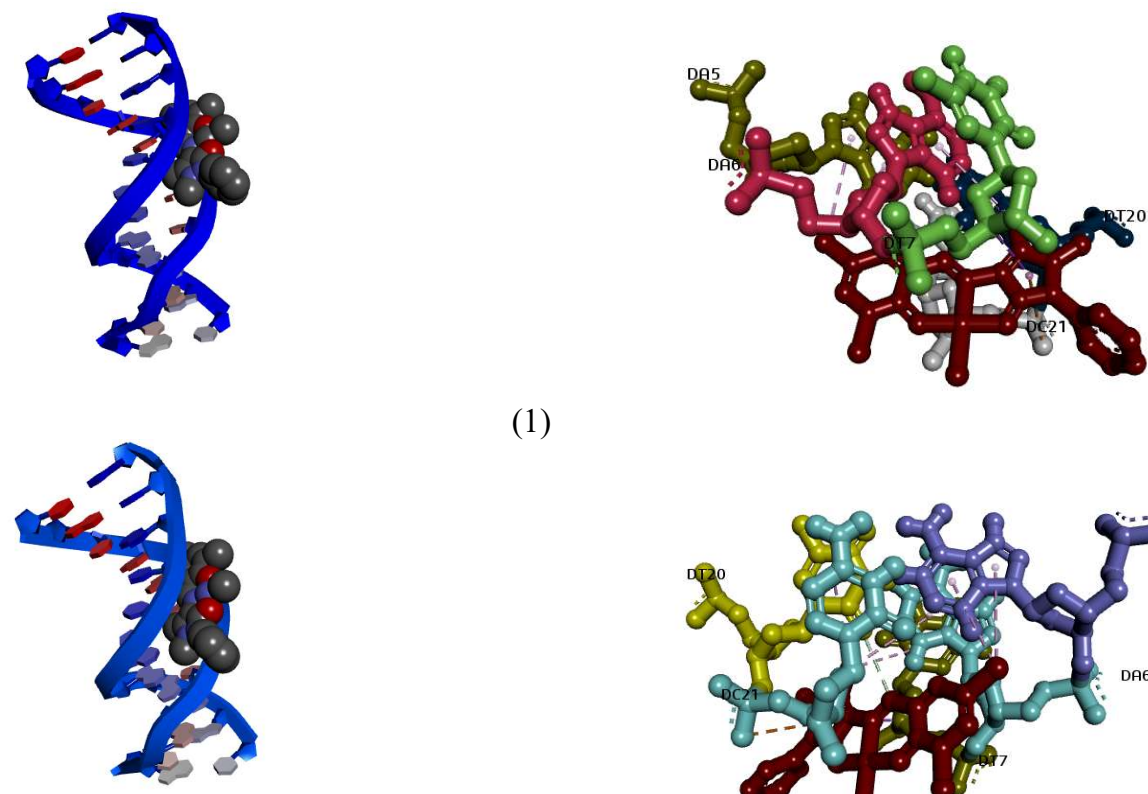

(1)

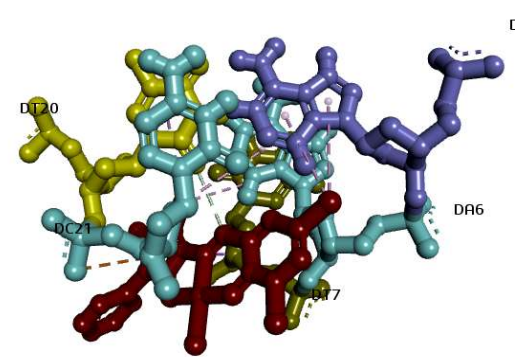

(2)
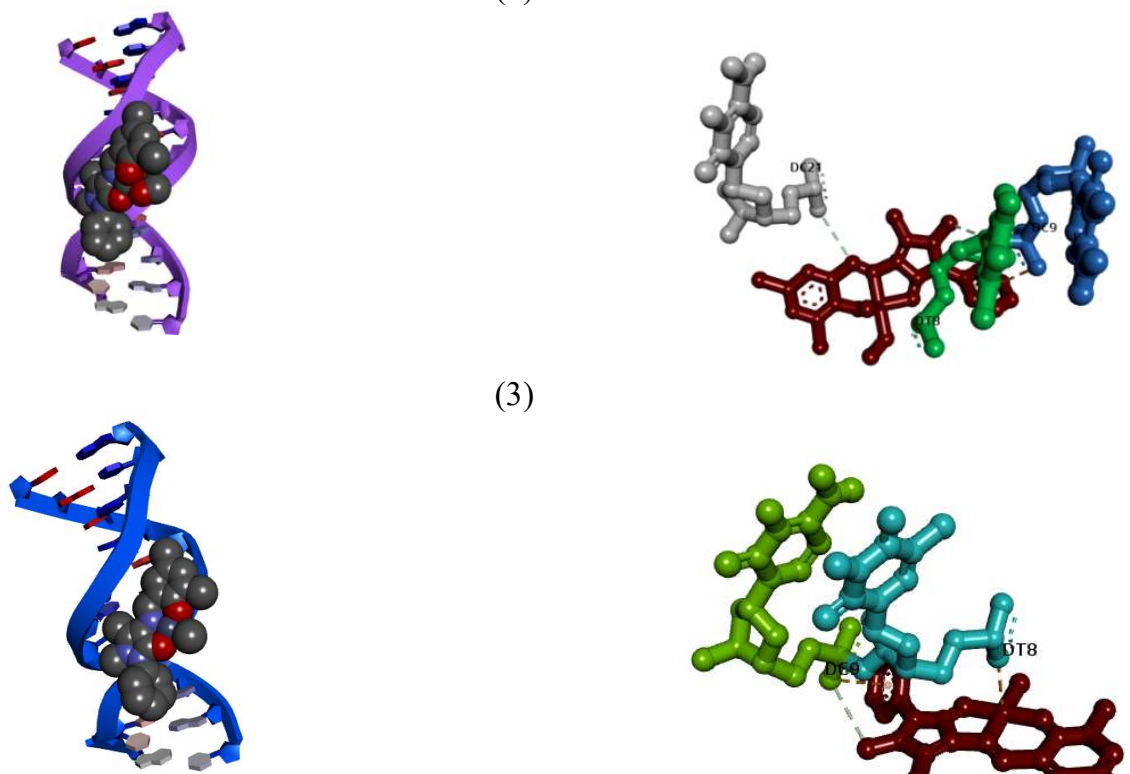

(3)

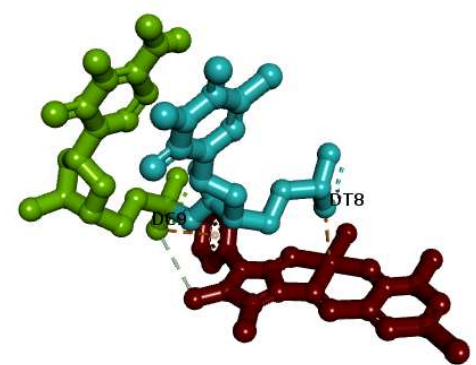

(4)

\section{Docking with BSA Protein}

Fig.-4: DNA Docking Studies of Complexes 1-4

The synthesized metal complexes 1 -12 interacted with the dengue protein Dengue Dengue NS3 proteasehelicase (PDB ID: 2VBC) biomolecule. There are two side chains were present in the target receptor. Using docking study, we can analyze the binding energy, binding mode, and the binding interaction of the drug-protein. There are nine possible confirmers are available. The best mode of binding is selected and shown in Fig.-5. Several amino acid residues were involved in the binding study. The amino acid residues THR289, ALA452, SER453, LYS430, ARG599, LEU443, PRO291, HIS487, ASP409, HIS487, PRO431, PRO543, ALA406, CYS292, PRO291, ALA606, LEU429, HIS487, ALA602, ALA606, PRO543, ASP409, and HIS487. The amino acid residues interacted by the drugs atom by using pi-alkyl, pi-pi stacked, H-bonding and Vaner Waals weak interactions. The interaction values and the mode were noted 
RASĀYAN J. Chem.

Vol. 14 | No. 2 |1230-1239| April - June | 2021

in the Table-4. The best three complexes with increasing order of binding energy is $1>4>2>3$. Complex 1 having the best binding interaction towards the dengue virus protein.

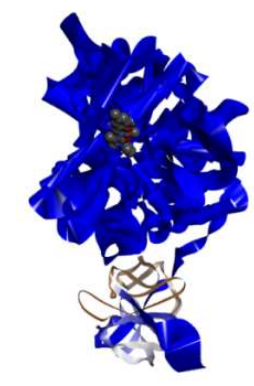

(1)
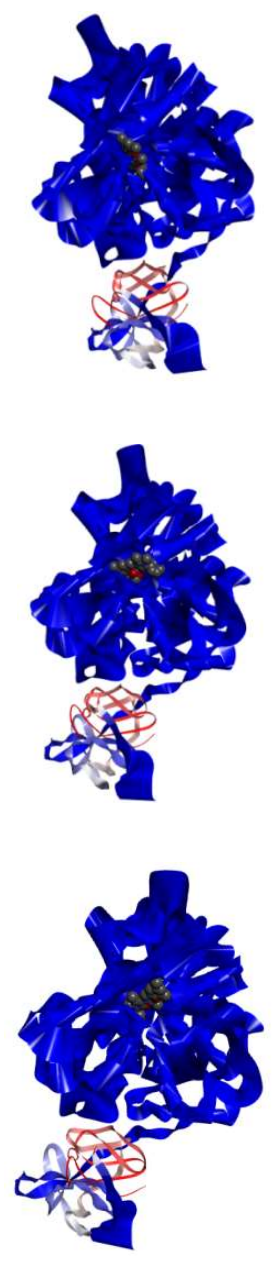

(2)

(3)
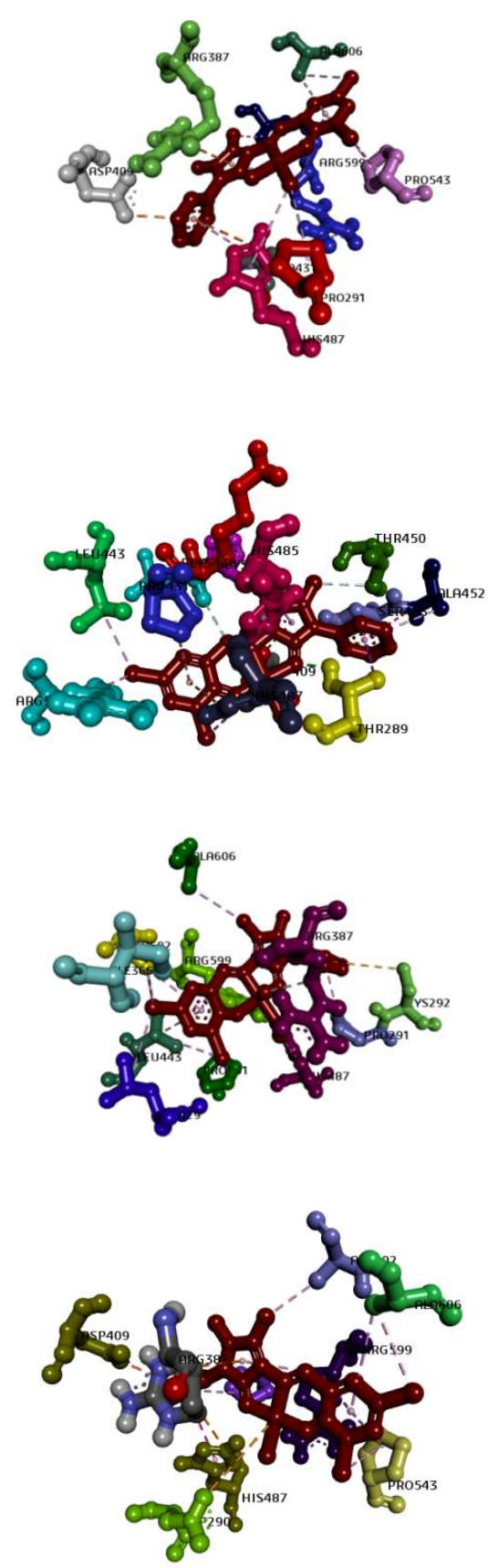

(4)

Fig.-5: Dengue Protein Docking Studies of Complexes 1-4

Table-4: Docking Interactions of Complexes 1-4 with Dengue Virus Protein

\begin{tabular}{c|c|c|c|c}
\hline 1 & C6-11 & THR289 & -9.0 & 3.61 \\
\hline & C6-11 & ALA452 & & 5.27 \\
\hline & C6-11 & SER453 & & 5.53 \\
\hline & C15 & LYS430 & & 4.35 \\
\hline & C127 & ARG599 & & 3.68 \\
\hline & C127 & LEU443 & & 4.13 \\
\hline
\end{tabular}


RASĀYAN J. Chem.

Vol. 14 | No. 2 |1230-1239| April - June | 2021

\begin{tabular}{c|c|c|c|c}
\hline 2 & $\mathrm{Cl26}$ & PRO291 & -8.8 & 4.97 \\
\hline & $\mathrm{C} 126$ & HIS487 & & 5.06 \\
\hline & $\mathrm{C} 6-11$ & ASP409 & & 3.97 \\
\hline & $\mathrm{C6-11}$ & HIS487 & & 4.42 \\
\hline & $\mathrm{C6}-11$ & PRO431 & & 5.43 \\
\hline & $\mathrm{C} 16-21$ & PRO543 & & 3.99 \\
\hline & $\mathrm{C} 16-21$ & ALA406 & & 5.03 \\
\hline 3 & $\mathrm{C6}-11$ & CYS292 & -8.6 & 5.71 \\
\hline & $\mathrm{C6-11}$ & PRO291 & & 4.76 \\
\hline & $\mathrm{C} 15$ & ALA606 & & 4.20 \\
\hline & $\mathrm{Cl27}$ & LEU429 & & 4.76 \\
\hline & $\mathrm{Cl22}$ & HIS487 & & 4.62 \\
\hline 4 & $\mathrm{C} 15$ & ALA602 & -8.9 & 3.89 \\
\hline & $\mathrm{C} 16-21$ & ALA606 & & 5.21 \\
\hline & $\mathrm{C} 16-21$ & PRO543 & & 4.57 \\
\hline & $\mathrm{C6-11}$ & ASP409 & & 4.00 \\
\hline & $\mathrm{C6}-11$ & HIS487 & & 4.38 \\
\hline
\end{tabular}

\section{CONCLUSION}

The Schiff base and metal complexes 1-4 were synthesized and characterized by various spectral methods. The complexes 1-4 were docked with both BSA protein and dengue virus. Complex 1 having the greater binding energy towards both B-DNA and NS3 protease-helicase.

\section{REFERENCES}

1. S.B. Halstead, Science. 239, 476(1988), DOI:10.1126/science.3277268

2. World Health Organization, Geneva(1997) 20 Avenue Appia, 1211 Geneva 27, Switzerland.

3. H.J. Kuo, I.K. Lee, J.W. Liu, Journal of Microbiology, Immunology and Infection, 51 740(2018), DOI: $10.1016 /$ j.jmii.2019.08.005

4. I.K. Lee, C.J. Hsieh, C.T. Lee, J.W. Liu, Journal of Microbiology, Immunology and Infection, 53, 69(2020).

5. A. Patil, S. Ganguly, and S. Surana, Rasayan Journal of Chemistry, 1, 447(2008).

6. N. Gupta, S. Srivastava, A. Jain, U.C. Chaturvedi, Indian Journal of Medical Research, 136, 373(2012).

7. W.M. Hammon, A. Rudnick, G.E. Sather, Viruses associated with epidemic hemorrhagic fevers of the Philippines and Thailand Science, 131, 1102(1960).

8. J.N. Mangione, N.T. Huy, N.T. Lan, E.C. Mbanefo, T.T. Ha, L.Q. Bao, Tropical Medicine and Health, 42, 137(2014).

9. I. Zivna, S. Green, D.W. Vaughn, S. Kalayanarooj, H.A. Stephens, D. Chandanayingyong, Journal of Immunology, 5959, 168(2002), DOI:10.4049/jimmunol.168.11.5959

10. T.L. Thein, E.L. Ng, M.S. Yeang, Y.S. Leo, D.C. Lye, Journal of Microbiology, Immunology and Infection, 50, 314(2017), DOI: 10.1016/j.jmii.2015.06.008

11. C.H. Huang, L.L. Kuo, K.D. Yang, P.S. Lin, P.L. Lu, C.C. Lin, Journal of Microbiology, Immunology and Infection, 46, 358(2013).

12. J. Camacho, A. Barazarte, N. Gamboa, J. Rodrigues, R. Rojas, A. Vaisberg, R. Gilman and J. Charris, Bioorganic \& Medicinal Chemistry, 19, 2023(2011), DOI:10.1016/j.bmc.2011.01.050

13. V. Gavali, Rasayan Journal of Chemistry, 10, 13(2017), DOI:10.7324/ RJC.2017.1011494

14. D.W. Vaughn, S. Green, S. Kalayanarooj, B.L. Innis, S. Nimmannitya, S. Suntayakorn, The Journal of Infectious Diseases, 181, 2(2000), DOI:10.1086/315215

15. M.G. Guzman, G. Kouri, E. Martinez, J. Bravo, R. Riveron, M. Soler, Bull Pan Am Health Organ, 21, 270(1987).

16. G.P. Kouri, M.G. Guzman, J.R. Bravo, C. Triana. Bull World Health Organ, 67, 375 (1989), DOI: $10.1007 / \mathrm{s} 00705-006-0869-\mathrm{X}$ 


\section{RASĀYAN J. Chem.}

Vol. 14 | No. 2 |1230-1239| April - June | 2021

17. S. Zompi, E. Harris, Animal Models of Dengue Virus Infection Viruses, 4, 62(2012), DOI: $10.3390 / \mathrm{v} 4010062$

18. M.S. Lee, Y.H. Tseng, Y.C. Chen, C.H. Kuo, S.L. Wang, M.H. Lin, Journal of Microbiology, Immunology and Infection, 51, 829(2018), DOI: 10.1016/j.jmii.2019.09.005

19. N.J. King, A.M. Kesson, Immunology and Cell Biology, 81, 207(2003).

20. A.T. Mairuhu, J. Wagenaar, D.P. Brandjes, E.C. van. European Journal of Clinical Microbiology \& Infectious Diseases, 23, 425(2004), DOI:10.1007/s10096-004-1145-1

21. S. Ubol, W. Phuklia, S. Kalayanarooj, N. Modhiran, The Journal of Infectious Diseases, 201, 923(2010), DOI:10.1086/651018

[RJC-6202/2020] 